\title{
Princípios Contratuais E EXIGÊNCIA DE FUNDAMENTAÇÃO DAS DECISÕES: BOA-FÉ E FUNÇÃO SOCIAL DO CONTRATO À LUZ DO CPC/2015
}

Carlos Nelson Konder*

\begin{abstract}
1Introdução. $2 \mathrm{O}$ novo CPC e a exigência de fundamentação das decisões. 3 A contribuição da teoria da argumentação para a fundamentação das decisões. 4 A peculiaridade dos princípios e sua importância no direito contratual contemporâneo. 5 As decisões que aplicam o princípio da boa-fé. 6 As decisões que aplicam a função social do contrato. 7 Conclusão. Referências.
\end{abstract}

\section{RESUMO}

O artigo analisa o impacto da introdução, pelo Código de Processo Civil de 2015, de parâmetros para que se possa avaliar a adequada fundamentação de uma decisão judicial sobre a aplicação dos princípios contratuais, mais especificamente, a boa-fé e a função social do contrato. Parte das contribuições da teoria da argumentação contemporânea, incorporadas pela doutrina processualista, em especial no que tange a estruturas normativas, como princípios, cláusulas gerais e conceitos indeterminados. Dedica-se, então, à observação de uma amostragem de decisões judiciais representativa das críticas doutrinárias, que afirmam a ocorrência de invocação meramente retórica dos princípios contratuais, como forma apenas de avalizar o entendimento pessoal do intérprete. Ao final, sinaliza instrumentos para que o intérprete possa se desincumbir mais adequadamente do ônus argumentativo de fundamentação das decisões, por meio de topoi discursivos sugeridos doutrinariamente ou positivados constitucionalmente, tal como as chamadas especializações funcionais ou figuras parcelares da boa-fé e os bens jurídicos referidos pelo constituinte aptos a dar conteúdo à função social do contrato, como educação, saúde, moradia e meio ambiente.

Palavras-chave: Fundamentação. Princípios. Boa-fé. Função social do contrato.

* Professor adjunto do Departamento de Direito Civil da Faculdade de Direito da UERJ. Professor do Departamento de Direito da PUC-Rio. Doutor e Mestre em Direito Civil pela UERJ. Especialista em Direito Civil pela Università di Camerino (Itália).E-mail: <c.konder@ gmail.com>. 


\section{INTRODUÇÃO}

A promulgação do novo Código Processo Civil, a Lei n. 13.105, em 16 de março de 2015, trouxe renovadas possibilidades não apenas para o Direito Processual, mas também para o ordenamento jurídico brasileiro como um todo. No decorrer de sua longa vacatio, foi possível aos intérpretes começar a perceber a extensão da transformação que ele oferece e, nos próximos tempos, prosseguiremos a vê-la em prática. Diversas interseções, em pontos específicos, entre o Direito Processual Civil e o Direito Civil saltam aos olhos, e vêm sendo objeto de abordagens não menos importantes pela doutrina. No entanto, aqui se optou por abordar uma transformação mais sutil e mais profunda que o CPC/2015 trouxe para um nível sistêmico, que se irradia não só para o Direito Civil, como também para todos os ramos do Direito: a fundamentação das decisões.

Em especial, merece atenção cuidadosa do intérprete a forma como o novo Código guiou a fundamentação das decisões que se baseiam em cláusulas gerais, conceitos indeterminados e princípios. Respondendo a um anseio, o legislador buscou conduzir a argumentação dos magistrados de forma mais precisa no que tange à utilização dessas figuras normativas que, se não são novas, ganharam protagonismo nunca visto até então, e, com isso, ainda podem ser objeto de invocação de forma inapropriada com as exigências de democraticidade e segurança jurídica afetas ao nosso Estado de Direito.

Nesse texto, a análise se detém sobre as decisões que invocam as mais populares estruturas normativas do direito contratual contemporâneo: a boa-fé e a função social do contrato. Buscar-se-á observar as dificuldades sofridas na implementação de uma eficácia real e autônoma dessas disposições e como as instruções oferecidas pelo CPC/2015 podem colaborar nesse processo.

\section{O NOVO CPC E A EXIGÊNCIA DE FUNDAMENTAÇÃO DAS DECISÕES}

Uma das principais marcas metodológicas impressas na elaboração do novo Código de Processo Civil de 2015 é a chamada constitucionalização dos vários ramos do Direito. A consciência de que a supremacia normativa da Constituição e a unidade do ordenamento não se constituem apenas sob a perspectiva formal, mas exigem também um esforço hermenêutico para imantar as diversas normas do sistema com os mesmos preceitos fundamentais, implica a releitura dos diversos setores do ordenamento à luz dos direitos fundamentais e dos princípios constitucionais.

No âmbito do Direito Processual, isso foi referido como "neoprocessualismo", o qual, nos termos de André Vasconcelos Roque, configura verdadeira simbiose com o neoconstitucionalismo, retirando dele suas premissas e oferecendo, em troca, a contenção do arbítrio judicial, a qual se viabiliza, especialmente, pelo dever de motivação das decisões, que oferece não apenas meios para as partes recorrerem, mas também para que a própria sociedade possa controlar 
a atuação dos juízes. ${ }^{1}$ De fato, o novo diploma processual foi produzido como fruto de uma democracia deliberativa que reconhece como legítimo apenas o domínio da razão, em que, nas palavras de Luiz Fux, os anseios se manifestam "em uma arena onde o único duelo esperado é o da argumentação."

Trata-se da superação da miopia de uma visão que, excessivamente centrada na celeridade processual, tornou-se contraproducente, já que as decisões proferidas sem o devido cuidado, para atender às estatísticas, acabavam por ser anuladas em grau de recurso, ao final, retardando ainda mais o tempo do processo. À exigência de uma duração razoável do processo, somou-se a maior atenção ao seu desenrolar cuidadoso, sob a crença de que "com decisões mais bem fundamentadas, após uma cognição mais bem preparada [...], confia-se na diminuição das enormes taxas de reforma, fruto do atual debate superficial."3

A partir do clássico pioneiro de Michele Taruffo, ${ }^{4}$ os estudos processuais sobre a fundamentação das decisões judiciais deixaram o exame puramente exegético-normativo, inspirado no modelo silogístico, para aportar as contribuições de autores como Esser e Hart também a valoração de provas e análise de fatos, realçando a necessidade de completude da motivação. Nessa linha, determina o art. 489 do novo CPC:

Art. 489. São elementos essenciais da sentença:

I - o relatório, que conterá os nomes das partes, a identificação do caso, com a suma do pedido e da contestação, e o registro das principais ocorrências havidas no andamento do processo;

II - os fundamentos, em que o juiz analisará as questões de fato e de direito;

III - o dispositivo, em que o juiz resolverá as questões principais que as partes the submeterem.

$\S 1^{\circ}$ Não se considera fundamentada qualquer decisão judicial, seja ela interlocutória, sentença ou acórdão, que:

I - se limitar à indicação, à reprodução ou à paráfrase de ato normativo, sem explicar sua relação com a causa ou a questão decidida;

II - empregar conceitos jurídicos indeterminados, sem explicar o motivo concreto de sua incidência no caso;

III - invocar motivos que se prestariam a justificar qualquer outra decisão;

IV - não enfrentar todos os argumentos deduzidos no processo capazes de, em tese, infirmar a conclusão adotada pelo julgador;

$\mathrm{V}$ - se limitar a invocar precedente ou enunciado de súmula, sem identificar seus fundamentos determinantes nem demonstrar que o caso sob julgamento se ajusta àqueles fundamentos;

VI - deixar de seguir enunciado de súmula, jurisprudência ou 
precedente invocado pela parte, sem demonstrar a existência de distinção no caso em julgamento ou a superação do entendimento.

$\S 2^{\circ}$ No caso de colisão entre normas, o juiz deve justificar o objeto e os critérios gerais da ponderação efetuada, enunciando as razões que autorizam a interferência na norma afastada e as premissas fáticas que fundamentam a conclusão.

$\S 3^{\circ}$ A decisão judicial deve ser interpretada a partir da conjugação de todos os seus elementos e em conformidade com o princípio da boa-fé.

O dispositivo encontra seu fundamento no art. 93, IX, da Constituição, que determina que "todos os julgamentos dos órgãos do Poder Judiciário serão públicos, e fundamentadas todas as decisões, sob pena de nulidade [...]". No entanto, a exigência constitucional era, até então, cumprida apenas formalmente, sem observância do conteúdo material que deveria revestir uma fundamentação democrática. Forte crítica se estabeleceu contra a tendência, em decisões, de fundamentar a utilização de princípios de forma silogística, como se fossem regras, invocando-os como argumentos de autoridade, sem a devida argumentação. Trata-se do que já foi chamado de "carnavalização do Direito," ${ }^{5}$ "panprincipialismo," " "pós-positivismo à brasileira" e "decisionismo judicial," 8 que seria, de maneira geral, a prática de invocar princípios de conteúdo aberto para decidir, mas sem qualquer exposição analítica sobre o significado do enunciado normativo e sua aplicação ao caso concreto, utilizando-os nos moldes subsuntivos normalmente usados para a aplicação de regras. Essa prática viabiliza que o magistrado resolva o conflito principiológico exclusivamente a partir de sua consciência, servindo a invocação do princípio apenas para referendá-lo, sem explicitar o passo a passo da sua decisão. ${ }^{9}$

Contra isso, afirma-se a nulidade da decisão que se socorrer dessas estruturas normativas "sem explicar o motivo concreto de sua incidência no caso", que "invocar motivos que se prestariam a justificar qualquer outra decisão", ou que lidar com um conflito entre princípios sem "justificar o objeto e os critérios gerais da ponderação efetuada, enunciando as razões que autorizam a interferência na norma afastada e as premissas fáticas que fundamentam a conclusão". O dispositivo dirige-se, assim, a um "definitivo abandono do formalismo ingênuo e redutor do sistema anterior", contribuindo como instrumento para a consolidação de uma jurisdição mais adequada às exigências democráticas da Constituição de $1988 .{ }^{10}$ Serve a coibir, também, a prática recorrente de utilização da mesma fundamentação para diversos casos distintos, na medida em que torna "nula a decisão que possua fundamentação genérica, compreendida esta como aquela que poderia ser utilizada para qualquer caso abstratamente."11

\section{A CONTRIBUIÇÃO DA TEORIA DA ARGUMENTAÇÃO PARA A FUNDAMENTA̧ÇÃO DAS DECISÕES}

A exigência processual de motivação, de base constitucional é enriquecida pelo aporte científico, trazido, nas últimas décadas, pela chamada Teoria 
da Argumentação. Construiu-se ali a possibilidade de legitimação científica de decisões guiadas pelo esforço de persuasão e convencimento, bem como pautadas pela busca do razoável e do adequado. ${ }^{12}$ Os trabalhos de autores como Perelman e Alexy contribuíram para desconstruir o entendimento de que somente o raciocínio pautado pela lógica formal da matemática seria dotado de cientificidade, e, portanto, a argumentação jurídica estava fadada ao decisionismo próprio de um ato de vontade. Perelman supera a premissa, baseada no modelo cartesiano de ciência, de que a racionalidade está restrita ao raciocínio more geometrico e à técnica da demonstração pela evidência, verificando que os recursos discursivos desenvolvidos para provocar o assentimento e a adesão de um auditório são reflexos de que o poder de deliberar e argumentar também são guiados por uma racionalidade própria. ${ }^{13}$ Alexy indica que esse modo de pensar, orientado por valores e cuja lógica não é de tipo formal, também é pautado por uma racionalidade e pode igualmente ser objeto de análise científica, que se vincula a uma pretensão de correção. ${ }^{14}$

É possível, assim, exigir que a fundamentação das decisões seja dirigida pelo postulado da razoabilidade, ${ }^{15}$ construído com base em um discurso não apenas de justificação, mas também de adequação das normas, que fundamenta a preferência pelo princípio aplicável ao caso concreto, e que assim viabiliza a aceitação racional das decisões judiciais com base na qualidade dos argumentos levantados, cuja verificação permite que o processo argumentativo seja concluído quando, desse todo coerente, resultar um acordo racionalmente motivado. ${ }^{16}$

As escolhas do intérprete devem ser assumidas expressamente, não como forma a libertá-lo do Direito institucionalizado, mas exatamente para permitir o debate argumentativo acerca da sua adequação ao ordenamento: trata-se da responsabilidade do intérprete. ${ }^{17}$ Por meio da fundamentação, verificam-se os argumentos que levaram o intérprete a escolher, é nela em que encontramos os parâmetros para compreender a decisão. ${ }^{18}$ Pela fundamentação, verifica-se se os elementos extrajurídicos foram absorvidos por meio de elementos normativos, se os valores referidos são sociais e culturais e não pessoais: viabiliza-se, em última instância, um controle final sobre os argumentos adotados. ${ }^{19}$ Isso significa que a derrubada do limite externo, formal, que restringia o intérprete - o dogma da subsunção - não importa a consagração do arbítrio, mas sim a imposição de um limite interno, metodológico: a exigência de fundamentação das decisões judiciais. A ampliação da área de liberdade conferida aos magistrados, em comparação com a tradição de nossa história jurídica, impõe uma atenção maior às justificativas invocadas para essas decisões. ${ }^{20}$ Nessa linha, ainda que os magistrados tomem decisões partindo de visões pessoais ou mesmo preconceitos e depois busquem as premissas para fundamentá-las, isso não significa descartar a importância e a necessidade da fundamentação. ${ }^{21}$ 


\section{A PECULIARIDADE DOS PRINCÍPIOS E SUA IMPORTÂNCIA NO DIREITO CONTRATUAL CONTEMPORÂNEO}

O desafio relativo à fundamentação das decisões - e importância da atenção a este ponto - é ainda maior quando se trata de decisões que aplicam conceitos indeterminados, cláusulas gerais e princípios. Foi a proliferação desse tipo de estrutura normativa, associada à mudança na própria metodologia hermenêutica dominante, que produziu - ou deveria produzir - impacto sobre o processo de fundamentação das decisões. Os princípios, bem como os conceitos indeterminados e as cláusulas gerais, acabam por contribuir para a exigência de modificação da forma de fundamentação das decisões, pois impõem um ônus argumentativo diferenciado ao intérprete. A técnica regulamentar, que se opõe a essas estruturas normativas, contribui para viabilizar formalmente a fundamentação das decisões sob o modelo da subsunção, em que a decisão se extrai de um suposto silogismo lógico formal, como uma escolha necessária e neutra. Já os conceitos indeterminados, as cláusulas gerais e os princípios, ao abrirem explicitamente a liberdade de decisão do intérprete para a pluralidade e imprevisibilidade dos casos concretos, esvaziam a possibilidade de mascarar as escolhas valorativas do intérprete, inafastáveis do processo decisório, sob a máscara do raciocínio subsuntivo. Tais escolhas passam a dever ser explicitadas, de maneira a poderem ser submetidas ao crivo crítico dos demais.

Reputada uma das marcas da transformação do Direito ao longo do século XX, percebe-se claramente no âmbito do Direito contratual brasileiro o recurso cada vez maior a essas estruturas normativas que reconhecidamente atribuem - ou reconhecem - ao intérprete um poder maior de "concreção."22 Diante da insuficiência do modelo subsuntivo e da inexorável liberdade do intérprete na construção da norma, o próprio legislador contribui oferecendo enunciados normativos mais abertos e flexíveis para viabilizar não apenas a adaptação da norma à imprevisibilidade da vida, mas o próprio preenchimento valorativo à luz do influxo de normas superiores em diálogo com as circunstâncias do caso concreto.

Adotando a taxonomia de Engisch, ${ }^{23}$ fala-se de conceitos jurídicos indeterminados, cláusulas gerais e princípios. No âmbito do Direito contratual brasileiro, percebe-se que o legislador de 2002, nas parcas alterações que fez comparativamente ao Código Civil de 1916, intensificou o uso de conceitos indeterminados, que, a despeito de um núcleo duro, trazem um halo conceitual difuso, que lhes traz a marca característica de conteúdo e extensão em larga medida incertos. ${ }^{24}$ Assim, por exemplo, a irrenunciabilidade, em contratos de adesão, a "direito resultante da natureza do negócio" (CC, art. 422), a modificação da contagem de prazo para redibição quando "o vício, por sua

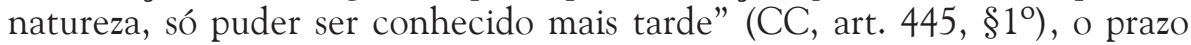
para a resilição do contrato proporcional aos "investimentos consideráveis para sua execução" (CC, art. 473, parágrafo único), ou ainda a resolução do contrato quando sua execução "se tornar excessivamente onerosa, com ex- 
trema vantagem para a outra, em virtude de acontecimentos extraordinários e imprevisíveis" (CC, art. 478).

No entanto, para além de um aumento de termos de maior vagueza semântica, reconhece-se na legislação contratual contemporânea o recurso expresso à técnica legislativa das cláusulas gerais, as quais, contrapondo-se à elaboração casuística das hipóteses legais, que circunscreve particulares grupos na sua especificidade própria (fattispecie), abrange e submete a tratamento jurídico todo um domínio de casos, em termos de grande generalidade. ${ }^{25}$ Essas disposições normativas utilizam intencionalmente uma linguagem aberta e fluida com o objetivo de conferir ao juiz "um mandato (ou competência) para que, à vista dos casos concretos, crie, complemente, ou desenvolva normas jurídicas."26

Louvada como uma das grandes inovações do projeto, ${ }^{27}$ no âmbito específico do Direito contratual, é destacada a determinação de que "a liberdade de contratar será exercida em razão e nos limites da função social do contrato" (CC, art. 421) e que "os contratantes são obrigados a guardar, assim na conclusão do contrato, como em sua execução, os princípios de probidade e boa-fé" (CC, art. 422). As espécies em questão não são excludentes, já que, como se pode observar, muitas dessas cláusulas gerais são construídas com recurso a conceitos indeterminados e, ainda, muitas delas servem a veicular, também, princípios jurídicos. ${ }^{28}$

De fato, uma terceira estrutura normativa simbólica desse contexto de modificação são os princípios, em virtude de seu papel na atividade hermenêutica. Tradicionalmente considerados quase que exclusivamente em sua função informadora e ordenadora, cuja aplicação era sempre subsidiária, condicionada à existência de uma lacuna das regras específicas, aos princípios, passou-se a reconhecer força normativa: as normas seriam um gênero dentro do qual são espécies não apenas as regras, mas também os princípios. ${ }^{29}$ Nesse sentido, difundiu-se a posição de Robert Alexy, que concebe os princípios como mandados de "otimização", que determinam que algo seja realizado na maior medida possível. ${ }^{30}$ Nesse sentido, os princípios distinguem-se dos valores apenas no fato de que os primeiros se situam no plano deontológico (dever ser), enquanto os segundos se encontram no plano axiológico (bem). De outro lado, os princípios são também espécies do gênero norma, assim como as regras (razões definitivas), das quais se diferenciam porque não se aplicam em qualquer situação (razões prima facie). Desse modo, a solução de um conflito entre princípios é resolvida na dimensão do peso (e não da validade, como nas regras), por meio de uma ponderação, uma hierarquização no caso concreto.

Outra corrente, seguida por Klaus Günther e Jürgen Habermas a partir do pensamento de Ronald Dworkin, ${ }^{31}$ defende que o procedimento sugerido por Alexy para solucionar o problema da colisão de princípios os esvazia de seu caráter normativo, conduzindo a uma criticável concepção axiologizante do direito. ${ }^{32}$ Tal mecanismo de preferência e mensuração condiz somente com o tratamento de valores. Se princípios são normas, então atuam no plano do agir 
obrigatório, não do teleológico. ${ }^{33}$ Consequentemente, não podem ter somente uma preferência no caso concreto ou ser aplicados na medida do possível, pois uma norma não pode ter uma pretensão de validade gradual. ${ }^{34}$ Para, então, entender o mecanismo de aplicação dos princípios, é imprescindível observar a distinção entre o plano da justificação, em que os princípios encontram sua fundamentação, e o plano da aplicação, em que se discute a adequação do princípio a um caso concreto. Assim, dois princípios aparentemente contraditórios no plano da justificação são apenas concorrentes no plano da aplicação. ${ }^{35}$ Diversamente das regras, que se aplicam de maneira "tudo ou nada," ${ }^{36}$ com exceções previamente enumeráveis, um princípio excepciona a aplicação do outro em virtude de circunstâncias características do caso concreto. ${ }^{37} \mathrm{E}$ um procedimento que não supõe uma gradação, mas uma cessão; que não toca ao plano da validade, mas ao da aplicação. Os princípios são, então, definidos, em oposição às regras, como normas cujas condições de aplicação não são pré-determinadas. ${ }^{38}$

As correntes convergem, para os fins relevantes do presente trabalho, no sentido de identificar como o procedimento próprio para a solução dos casos em que existam princípios concorrentes, a oferecerem soluções diversas para o caso concreto, impõem ao intérprete um papel de maior protagonismo na construção da solução correta. No caso do Direito contratual, ao lado dos princípios da boa-fé e da função social, veiculados expressamente por cláusulas gerais, são reconhecidos princípios implícitos, como o equilíbrio econômico e a proteção dos vulneráveis, todos inspirados por uma lógica solidarista de matriz constitucional. Todavia, reconhece-se, também, a manutenção de princípios clássicos de matriz liberal, como a liberdade de contratar, a relatividade dos efeitos, a força obrigatória e a intangibilidade do conteúdo do contrato. A importância desses princípios, cuja força normativa passa a ser reconhecida, impõe ao intérprete um ônus argumentativo maior na solução dos conflitos que travam entre si. Somados à ampliação dos conceitos indeterminados e das cláusulas gerais, constata-se um contexto no qual se destaca o papel da fundamentação argumentativa das decisões judiciais no âmbito do Direito contratual.

\section{AS DECISÕES QUE APLICAM O PRINCÍPIO DA BOA-FÉ}

A consagração do princípio da boa-fé em nosso ordenamento, primeiro no âmbito do Código de Defesa do Consumidor, depois no Código Civil de 2002, tem sido considerada motor de significativa revolução no regime jurídico dos contratos. Compreendida não mais em sua acepção subjetiva, isto é, como estado do agente que ignora a existência de vícios em sua conduta, a boa-fé foi alçada à condição de princípio com força normativa, mandamento de conduta que impõe comportamento leal e honesto entre os contratantes. ${ }^{39}$

A introdução desse princípio torna mais complexa a compreensão da relação obrigacional. Em lugar da estrutura simplificada direito subjetivo - dever jurídico, passa-se a reconhecer diversas outras situações jurídicas subjetivas conjugadas - uma "pluralidade de elementos autonomizáveis" -, em especial 
deveres paralelos que interagem entre si e cujo inadimplemento pode ferir o todo obrigacional. Torna também mais dinâmica essa compreensão da relação obrigacional, pois passa a ser concebida como um conjunto de momentos sucessivos, interligados em unidade ontológica, uma estrutura verdadeiramente orgânica, repleta de relações recíprocas de instrumentalidade ou interdependência. A clássica e estática obrigação passa, como relação obrigacional, a ser compreendida como um sistema de processos em razão da necessária colaboração entre os sujeitos vinculados. Contribui, ainda, para a adoção de uma perspectiva funcional: a totalidade obrigacional existe em razão de um fim, que a polariza e dinamiza, que é o adimplemento. Todos os direitos, subjetivos e potestativos, ônus e deveres, poderes e faculdades, toda a situação jurídica complexa tem existência temporária orientada a atingir um fim objetivamente considerado, que deve concretizar-se em um conjunto de interesses merecedor de tutela.

A transformação não é puramente conceitual, pois implica a reformulação das regras aplicáveis às obrigações. Determinar se a obrigação foi ou não cumprida passa a ser tarefa árdua, na medida em que a própria determinação do adimplemento - e do inadimplemento - se transforma. Verifica-se o alargamento do objeto da obrigação e da flexibilização do termo adimplemento, já que a conduta exigível dos sujeitos envolvidos passa a incluir também colaboração e lealdade recíprocas. Dessa forma, produz-se uma verdadeira revolução no processo decisório, que não mais se pauta apenas pela realização ou não da prestação contratada: atribui-se ao juiz o poder de avaliar se a forma de cumprimento da prestação atendeu às expectativas legítimas do outro contratante. Em poucas palavras, pode o magistrado decidir sobre a execução do contrato com base, essencialmente, no que considera ser a "confiança" construída entre as partes.

Não é à toa que esse cenário, por um lado, extremamente promissor e repleto de possibilidades, seja também, por outro lado, bastante preocupante e exija a reflexão apresentada sobre a fundamentação dessas decisões. A invocação genérica da exigência de correção, lealdade, honestidade e transparência nas relações contratuais coloca novamente em jogo as dificuldades oriundas da utilização de princípios, cláusulas gerais e conceitos indeterminados na fundamentação das decisões.

O exame da jurisprudência recente é indicativo disso. Em que pesem ricas e inovadoras decisões que se utilizam adequadamente do princípio em questão, não é incomum que a menção à "boa-fé" venha revestida daquelas mesmas características que a nova legislação processual visa a combater. Tomando como exemplo alguns acórdãos do TJERJ publicados pouco antes da vigência do novo CPC, o uso puramente retórico ou decorativo da menção ao princípio é perceptível em decisões que poderiam ser pautadas pela violação de um dever legal expresso, tais como assegurar o direito a parcelamento de dívida de fornecimento de água previsto em lei estadual, ${ }^{40}$ rever taxa de juros superior ao autorizado por lei, ${ }^{41}$ vedar a cobrança por estimativa já proibida por lei ${ }^{42} \mathrm{ou}$ sancionar o descumprimento do dever de trocar produto defeituoso. ${ }^{43} \mathrm{Na}$ mesma 
linha, não são poucas as decisões que fazem referência à boa-fé para tratar de hipóteses em que se trata de mero descumprimento de dever contratual expresso, não distinguindo o simples inadimplemento da fundamentação principiológica, como a recusa da seguradora ao pagamento integral da indenização, ${ }^{44} \mathrm{o}$ atraso na entrega de imóvel adquirido na planta ${ }^{45} \mathrm{o}$ inadimplemento do promitente comprador ${ }^{46}$ e a negativa de cobertura de plano de saúde contratado. ${ }^{47}$ Essas decisões contribuem para a superutilização e o consequente esvaziamento do significado do instituto, como já alertado pela doutrina civilista. ${ }^{48}$ No entanto, para o ponto aqui suscitado, parecem mais problemáticas as decisões em que, diante de uma controvérsia interpretativa, invocam a boa-fé sem deixar claro o trajeto argumentativo pelo qual ela conduziria a uma solução específica entre aquelas possíveis, como podem ser citadas aquelas referentes à inclusão de home care na cobertura do plano de saúde, ${ }^{49}$ à abusividade de reajuste de plano de saúde,$^{50}$ à reajuste de pensão desatualizada, ${ }^{51}$ ao condicionamento de resgate de contribuição de previdência privada ${ }^{52}$ e à invalidade de cláusula de decaimento. ${ }^{53}$

Para além da novel legislação processual, pode-se observar a relevante contribuição que a doutrina tem dado, e deve continuar a dar, esmiuçando as possibilidades hermenêuticas da boa-fé objetiva, a começar pela utilização da teoria de origem alemã que defendia uma tripartição funcional da boa-fé: parâmetro interpretativo-integrativo, limitação ao exercício de direitos e criação de deveres anexos. ${ }^{54}$

Assim, a boa-fé serviria primeiro a determinar o conteúdo e o alcance das cláusulas contratuais, atribuindo-lhes o significado mais condizente com as legítimas expectativas despertadas. Segundo, limitaria o exercício de direitos, reputando abusiva a invocação de um direito de forma contrária à confiança construída entre as partes. Terceiro, para além dos deveres principais e acessórios produzidos pela autonomia privada na celebração do contrato, a boa-fé imporia deveres ditos anexos, laterais ou instrumentais, que seriam decorrentes da exigência de uma conduta reta, leal e honesta. A divisão, embora não seja absoluta, pois as funções muitas vezes se confundem e sobrepõem, contribui para a invocação mais didática e sistemática da boa-fé objetiva. ${ }^{55}$

Junta-se a isso, a indicação das chamadas especializações funcionais ou figuras parcelares da boa-fé, que configuram determinados modelos ou padrões de conduta abusiva, cada um indicado por caracteres distintivos próprios, indicadores de por que naquela situação o exercício do direito confrontaria com a tutela da confiança e das legítimas expectativas. Figuras como o tu quoque, a supressio, o venire contra factum proprium e o duty to mitigate the loss têm o potencial de facilitar o processo argumentativo de fundamentação das decisões baseadas na boa-fé, identificando padrões de conduta já consolidados de forma geral como abusivos por violação a esses princípios. Cada uma delas traz topoi idôneos a concretizar de forma mais clara perante a comunidade de interlocutores a quebra de confiança antijurídica, tais como a falta de reciprocidade, a reiteração e a contradição. 
Certamente, essas figuras parcelares da boa-fé não são algum tipo de panaceia para as dificuldades na aplicação do princípio. Também elas são dotadas de generalidade e indeterminação suficiente a permitir sua utilização puramente retórica, sem a identificação dos argumentos necessários ao que se considera uma fundamentação adequada e racional da decisão judicial. ${ }^{56}$ No entanto, uma observação preliminar indica que isso acontece com menor frequência do que nas decisões que se baseiam diretamente e apenas no princípio por trás delas e que, portanto, podem ajudar o intérprete a se desincumbir adequadamente do ônus de fundamentar a decisão.

\section{AS DECISÕES QUE APLICAM A FUNÇÃO SOCIAL DO CONTRATO}

A função social do contrato não se beneficiou da longa trajetória histórica de que desfrutou a função social da propriedade, tampouco de uma referência expressa no texto constitucional, com a indicação de parâmetros para sua aplicação. Nenhuma Constituição brasileira fez expressa referência à função social do contrato, nem a de 1988, tampouco estabeleceu critérios de efetivação. Mesmo em doutrina, até o advento do Código de 2002, eram raríssimas as reflexões no âmbito do direito a respeito da função social do contrato. ${ }^{57}$ Isso ajuda a explicar a resistência à sua positivação. Na primeira versão do anteprojeto de Código Civil, o dispositivo que viria a se tornar o artigo 421 enunciava que "a liberdade de contratar somente será exercida em razão e nos limites da função social do contrato". A inclusão do vocábulo "somente" foi muito criticada, pois se temia que fizesse que o enunciado fosse interpretado de forma a exigir que a única função que o contrato pudesse ter fosse a social, em oposição à função que ele teria apenas para as partes. ${ }^{58}$ Assim, receava-se que as partes pudessem ficar adstritas a abdicar de seus próprios interesses para, ao contratar, servir somente à coletividade. As críticas à redação inicial fizeram que o termo "somente" fosse suprimido, e o dispositivo ganhasse a redação com que foi promulgado: "A liberdade de contratar será exercida em razão e nos limites da função social do contrato". No entanto, o receio quanto às potencialidades do dispositivo persistiram, agora com relação à expressão "em razão de": a liberdade de contratar deve ser exercida em razão de sua função social. Esse movimento de reticência ao dispositivo, que se poderia chamar "antifuncionalista", afirmava que a função social só poderia servir como limite, mas não se poderia exigir que ela fosse razão da tutela do contrato.

Isso desenhou um cenário no qual não são incomuns decisões que invocam a função social do contrato exclusivamente como reforço argumentativo, sem qualquer indicação de sua eficácia normativa específica. $O$ receio que se colocou quanto à função social do contrato, em virtude da ausência de uma evolução histórica do conceito e, principalmente, na falta de balizas do constituinte e do legislador acerca de sua aplicação, foi a ameaça de certo autoritarismo judicial, de invasão estatal das relações intersubjetivas, por meio de um mecanismo de controle da autonomia. Era necessário evitar que a abertura da 
cláusula geral do art. 421 não implicasse uma fórmula vazia que franqueasse tal julgamento ao mero arbítrio do juiz, de maneira que, com base na função social do contrato, "a ingerência do poder judiciário só restasse autorizada em hipóteses excepcionais." ${ }^{59}$

Assim, afirma-se que, buscando a compatibilização entre os interesses econômicos das partes e os interesses sociais, a "tendência hodierna em reconhecer a função social do contrato não implica em [sic] socialização das relações jurídicas" e que objetiva precipuamente "a promoção de maior justiça nas trocas econômicas, sem descurar, todavia, da segurança jurídica, decorrente da observância do pacta sunt servanda." ${ }^{60}$ São exemplificativas dessa orientação decisões suprimem, por violação à função social do contrato, condições de reajuste que oneram excessivamente o consumidor, ${ }^{61}$ cláusulas impeditivas de restituição do valor pago ${ }^{62}$ negativa de renovação automática de contrato mantido por mais de dez anos, ${ }^{63}$ multa excessiva em relação de consumo que afronta os dispositivos consumeristas, ${ }^{64}$ dispositivo proibitivo de purgação da mora pelo devedor ${ }^{65}$ cláusula abusiva de renúncia à indenização das benfeitorias, ${ }^{66}$ desligamento compulsório de empreendimento cooperativo. ${ }^{67} \mathrm{Na}$ mesma linha, a possibilidade de revisão judicial dos termos do contrato, quando desequilibrados, encontrou amparo reiteradamente na exigência de atendimento à sua função social. ${ }^{68}$

É importante observar que, na maior parte destas decisões, a função social do contrato vem invocada com outros princípios, o que corrobora a constatação de que essa interpretação acaba esvaziando a função social de qualquer utilidade autônoma, de qualquer repercussão prática que já não seja atendida por outros meios. É curioso observar, por rápida consulta no sítio do STJ, que dos 100 acórdãos que fazem menção à função social do contrato, desde que o Código de 2002 entrou em vigor, em 62, ela é citada com o princípio da boa-fé, 3 com um "princípio de eticidade" e 10 com a vedação ao enriquecimento sem causa. Isso sem contar as diversas vezes em que a função social do contrato é invocada apenas como fundamento axiológico de outro instituto, que se aplica diretamente ao caso, com a redução da cláusula penal e a proibição de cláusulas abusivas.

Por isso se afirma que essa postura interpretativa, frente à função social do contrato, é, na verdade, uma resistência à sua própria existência, uma vez que a leva a não ter qualquer relevância normativa, privando-a de qualquer conteúdo autônomo e de qualquer efeito prático. A melhor doutrina alerta que isso produz uma invocação banal e sem conteúdo da função social do contrato, que serve apenas para esvaziar suas potencialidades, em vez de auxiliar na individualização da sua eficácia jurídica própria ${ }^{69}$ Como explica Gustavo Tepedino:

A primeira delas [corrente] sustenta que a função social do contrato não é dotada de eficácia jurídica autônoma, sendo uma espécie de orientação de política legislativa constitucional, que revela sua importância e eficácia não em si mesma mas em diversos institutos que, como expressão da função social, autorizam ou justificam soluções normativas específicas, tais como a resolução 
por excessiva onerosidade (CC, art. 478), a lesão (CC, art. 157), a conversão do negócio jurídico (CC, art. 170), a simulação como causa de nulidade (CC, art. 167), e assim por diante. [...] tal posição acaba por esvaziar a importância da função social, vez que esta se expressaria por meio de institutos já positivados, presentes de forma difusa no ordenamento, prescindindo, por isso mesmo, de eficácia jurídica autônoma. ${ }^{70}$

A funcionalização dos institutos conduz ao entendimento de que a autonomia privada, em especial a liberdade de contratar, nunca é um valor em si, ela só será protegida enquanto corresponder a um interesse digno de tutela pelo ordenamento. ${ }^{71}$ Assim, enquanto no modelo liberal clássico, a intervenção legislativa seria entendida como um obstáculo ou restrição à autonomia privada, hoje se reconhece que, em sociedades desiguais, é a atuação do legislador e do poder público que garantem a efetiva liberdade da pessoa humana. É na expressão dessas condições e desses requisitos para a tutela jurídica da atividade negocial, na concretização desses limites - mais internos do que externos - sobre o poder normatizador do particular, que se deve encontrar o lócus de atuação da função social do contrato.

Afirma-se, assim, que a função social do contrato implica o condicionamento da tutela da liberdade de contratar interesses da coletividade. Trata-se da proibição de contratos que repercutam negativamente sobre a comunidade e da conservação ou tratamento diferenciado de contratos que repercutam positivamente junto à sociedade. Nessa terceira série de efeitos, já se enfatiza mais o caráter "social" da função que guia a normatização do contrato. A função do contrato tem de estar de acordo com certos interesses que são independentes das partes, afirmando-se assim que "a liberdade de contratar está limitada não só pela supremacia da ordem pública, mas também pela função social do contrato, que o condiciona ao atendimento do bem comum e dos fins sociais." 72

A indicação desses interesses sociais ou coletivos, contudo, não fica ao alvedrio do intérprete, que poderia impor um descabido viés assistencialista à atividade contratual, mascarado por uma fundamentação argumentativa obscura. Não são quaisquer interesses do grupo que devem ser atendidos, mas aqueles interesses positivados como merecedores de tutela. ${ }^{73} \mathrm{O}$ regulamento negocialmente estabelecido deve ser condizente com certos valores reputados socialmente relevantes, quais sejam, aqueles que se encontram positivados no ordenamento por meio dos princípios constitucionais. ${ }^{74}$ Nesse sentido, tal como ocorre quanto às diversas formas de propriedade, também para as diversas formas de contrato podem ser encontrados, no texto constitucional, os fins que devem ser alcançados para o merecimento de tutela, tais como a valorização do trabalho humano, a livre iniciativa, a dignidade humana, a justiça social, a soberania nacional, a livre concorrência, a defesa do consumidor, a proteção ao meio ambiente, o pleno emprego, a proteção das microempresas, etc. ${ }^{75}$

Eventualmente, isso pode significar proteger uma das partes também, por exemplo, quando o contrato se contrapõe à dignidade humana, pode ser 
a dignidade de uma das partes que esteja sendo lesada e que vai ser protegida pela extinção do contrato. ${ }^{76}$ Mas, nesses casos, o interesse tutelado é coletivo porque vai além do interesse das partes, podendo, em certos casos, até mesmo, se contrapor à vontade de ambos contratantes. Assim, a violação da função social do contrato ocorreria na hipótese de ficarem atingidos pelos efeitos do contrato interesses metaindividuais juridicamente relevantes, como se destaca também na jurisprudência:

Não ofende o princípio da função social do contrato a cláusula que prevê o pagamento de multa caso o contratante empregue um dos ex-funcionários ou representantes da contratada durante a vigência do acordo ou após decorridos 120 (cento e vinte) dias de sua extinção, porquanto não existe proibição a tal contratação, encontrando-se ausente qualquer interesse metaindividual, seja coletivo ou difuso. ${ }^{77}$

A consequência da proteção aos interesses da coletividade pode ser não apenas a privação de efeitos dos negócios que afrontam tais interesses, mas também a conservação ou o tratamento jurídico diferenciado de um contrato que tenha grande repercussão no atendimento de um interesse socialmente relevante. $\mathrm{Na}$ jurisprudência, podem ser identificadas decisões que, seguindo essa linha, invocam a função social do contrato para conferir tratamento jurídico diferenciado aos chamados "contratos de gaveta" no âmbito do Sistema Financeiro Habitacional (SFH) de modo a assegurar o acesso popular à moradia, ${ }^{78}$ para interpretar ampliativamente a cobertura do contrato de seguro-saúde de modo a assegurar o direito à saúde, ${ }^{79}$ para determinar o parcelamento de débito de usuário de serviço de fornecimento de eletricidade evitando, assim, que ocorra a sua interrupção, em nome da proteção à dignidade humana,${ }^{80}$ ou para condenar o fiador a se manter garantidor da locação na prorrogação automática do contrato por seu afastamento, genericamente, "ofender interesses sociais previstos na Constituição."

É importante destacar que, nessa esfera de efeitos, já se ressalta a relevância da função específica daquele contrato para determinar sua compatibilidade com a função social que lhe garante juridicidade..$^{82}$ Os efeitos aqui cominados, seja no tocante à privação de eficácia por incompatibilidade com interesses metaindividuais, seja no tocante ao tratamento diferenciado por atendimento àqueles interesses, só são determinados em virtude da comparação da finalidade daquele contrato individualizado com relação aos interesses coletivos. ${ }^{83}$

Em doutrina, indica-se o tratamento especial dado pela lei à assunção de débito hipotecário, ${ }^{84}$ com consentimento presumido em razão da relevância social desse tipo de dívida e o direito de preferência nos contratos agrários. ${ }^{85} \mathrm{Na}$ jurisprudência, por exemplo, na análise do merecimento de tutela da cláusula penal de um contrato de prestação de serviços, a fundamentação se diferencia na medida em que se trata da prestação de serviço educacional, e, em virtude dessa especificidade, a "limitação da multa moratória incidente sobre mensalidades escolares determinada na origem encontra amparo na função social do contrato." ${ }^{86} \mathrm{Na}$ mesma linha, a ruptura de um contrato de seguro é reputada especialmente injustificada por tratar-se o segurado de pessoa idosa. ${ }^{87}$ 
Mesmo hipóteses que se poderiam considerar enquadradas na esfera de efeitos de mera tutela de interesse das partes encontram justificativa em interesses coletivos na medida em que a razão da intervenção reequilibradora passa a ser uma especificidade funcional do contrato em exame. Por exemplo, a cláusula resolutiva que priva o devedor do direito a purgar a mora é especialmente abusiva por se tratar de um contrato de financiamento habitacional: "Isto porque o contrato, na modalidade apontada, contempla manifesto interesse social - obtenção de moradia." 88

Dessa forma, observa-se que a função social do contrato, de forma análoga à função social da propriedade, apresenta-se como um postulado metodológico-hermenêutico que leva o intérprete a submeter a tutela do direito individual ao atendimento de interesses coletivos. No entanto, a adequada fundamentação da decisão que a aplica deve explicitar interesses coletivos, envolvidos no caso concreto, que tenham sido positivados juridicamente, sob pena de recair em uma referência genérica, que mascare as escolhas pessoais do intérprete e que acaba por ressuscitar o receio de que a função social do contrato sirva de instrumento de autoritarismo, ou mesmo totalitarismo, judicial.

\section{CONCLUSÃO}

O panorama apresentado serve para destacar a relevância dos parâmetros indicados no artigo 489 do CPC/2015 referentes à fundamentação das decisões para a aplicação de princípios pelo Judiciário, em especial quanto à aplicação do princípio da boa-fé e à função social do contrato como fundamentos para a solução de litígios no âmbito do direito contratual.

O princípio da boa-fé produziu profunda transformação na regulamentação dos contratos e é um instrumento promissor para uma atuação do Judiciário comprometida com o estabelecimento de relações mais solidárias e com a promoção da dignidade da pessoa humana mesmo nas relações patrimoniais. No entanto, não era incomum, até agora, identificar decisões que faziam uso meramente retórico desse princípio, invocando-o sem a devida fundamentação argumentativa, somente para legitimar formalmente um entendimento pessoal do intérprete.

Da mesma forma, a função social do contrato foi acenada como grande inovação do Código Civil de 2002, que, de modo pioneiro, a previu expressamente como condição de tutela da liberdade de contratar. No entanto, a enorme resistência às suas possibilidades hermenêuticas, que poderiam levar a um autoritarismo judicial, conduziu à sua invocação genérica em muitas decisões, sem lhe reconhecer conteúdo autônomo ou indicar seus efeitos jurídicos específicos.

Acredita-se que os parâmetros de fundamentação judicial adequada impostos pelo CPC/2015 podem contribuir para que a invocação da boa-fé e da função social do contrato incorporem critérios e elementos que, como topoi 
argumentativos, facilitam a que o intérprete se desincumba do ônus argumentativo adequadamente, oferecendo decisões mais democráticas e previsíveis.

Nesse sentido, indicou-se, no âmbito da boa-fé, a utilização, nas fundamentações, da construção doutrinária de sua tríplice função, identificando suas figuras parcelares ou especializações funcionais, como o venire contra factum proprium, o tu quoque e a supressio, que já indicam modelos de comportamento mais específicos, reputados abusivos por frustração da confiança tutelada. Da mesma forma, quanto à função social do contrato, na invocação de interesses coletivos ou metaindividuais que interferem na tutela da liberdade contratual, foi indicada a referência a bens jurídicos positivados pelo constituinte, como a saúde, a moradia, a educação e o meio ambiente, que contribuem para que a fundamentação argumentativa se desloque da avaliação pessoal do intérprete para dentro do ordenamento jurídico.

\section{REFERÊNCIAS}

ALEXY, Robert. Teoria da Argumentação Jurídica. 2. ed. São Paulo: Landy, 2005.

ALEXY, Robert. Teoría de los Derechos Fundamentales. Madrid: Centro de Estudios Constitucionales, 1993.

ATIENZA, Manuel. As razões do Direito: teorias da argumentação jurídica. 3. ed. São Paulo: Landy, 2006.

ÁVILA, Humberto. Teoria dos princípios. 5. ed. São Paulo: Malheiros, 2006. AZEVEDO, Antônio Junqueira de. Diálogos com a doutrina. Revista trimestral de Direito Civil, Rio de Janeiro, n. 34, p. 299-308, abr./jun. 2008. Entrevista concedida.

AZEVEDO, Antônio Junqueira de. Princípios do novo direito contratual e desregulamentação do mercado - Direito de exclusividade nas relações contratuais de fornecimento - Função social do contrato e responsabilidade aquiliana do terceiro que contribui para o inadimplemento contratual. Revista dos Tribunais, São Paulo, n. 750, p. 113-120, abr. 1998.

BERCOVICI, Gilberto. A constituição de 1988 e a função social da propriedade. Revista de Direito Privado, São Paulo, v. 7, p. 69-84, jul./set. 2001.

BOBBIO, Norberto. Dalla strutura alla funzione. Milano: Edizioni di Comunità, 1977.

BONAVIDES, Paulo. Curso de Direito Constitucional. São Paulo: Malheiros, 2000.

CAMARGO, Margarida Lacombe. Hermenêutica e argumentação: uma contribuição ao estudo do Direito. 3. ed. Rio de Janeiro: Renovar, 2003. 
CARDOSO, Patrícia Silva. Oponibilidade dos efeitos dos contratos: determinante da responsabilidade civil do terceiro que coopera com o devedor na violação do pacto contratual. Revista Trimestral de Direito Civil, Rio de Janeiro, n. 20, p. 125-150, out./dez. 2004.

CAVALIERI FILHO, Sérgio. O novo Código Civil e o Código do Consumidor: convergências ou antinomias. Revista da EMERJ, Rio de Janeiro, v. 5, n. 20, p. 100-114, 2002.

CORDEIRO, António Menezes. Da boa-fé no Direito Civil. Coimbra: Almedina, 1997.

CORTIANO JUNIOR, Eroulths. A função social dos contratos e dos direitos reais e o art. 2035 do Código Civil brasileiro: um acórdão do Superior Tribunal de Justiça. In: TEPEDINO, Gustavo; FACHIN, Luiz Edson (Coord.). O Direito e o tempo: embates jurídicos e utopias contemporâneas. Rio de Janeiro: Renovar, 2008. p. 359-368.

COSTA, Pedro de Oliveira. Apontamentos para uma visão abrangente da função social dos contratos. In: TEPEDINO, Gustavo (Org.). Obrigações: estudos sob a perspectiva civil-constitucional. Rio de Janeiro: Renovar, 2005. p. 45-68.

CUNHA, Paulo Ferreira da. Propriedade e função social. Revista de Direito Imobiliário, São Paulo, v. 56, p. 114-126, jan./jun. 2004.

DÍEZ-PICAZO, Luis. Fundamentos del Derecho Civil patrimonial. 5. ed. Madrid: Civitas, 1996. v. 1.

DWORKIN, Ronald. Levando os direitos a sério. São Paulo: Martins Fontes, 2002.

EHRHARDT JR., Marcos. Responsabilidade Civil pelo inadimplemento da boa-fé. Belo Horizonte: Forum, 2014.

EISTER, Allan W. Função. Dicionário de Ciências Sociais. Rio de Janeiro: Fundação Getúlio Vargas, 1986.

ENGISCH, Karl. Introdução ao pensamento jurídico. 10. ed. Lisboa: Fundação Calouste Gulbenkian, 2008.

ENGISCH, Karl. La idea de concreción en el Derecho y en la Ciencia Jurídica actuales. Pamplona: Universidad de Navarra, 1968.

FERREIRA, Carlos Alberto Goulart. Contrato: da função social. Revista Jurídica, Porto Alegre, n. 247, p. 9-15, maio 1998.

FUX, Luiz. Prefácio. In: FREIRE, Alexandre et al. (Org.). Novas tendências do Processo Civil: estudos sobre o projeto de novo Código de Processo Civil. Salvador: Juspodium, 2013. p. 9-12.

GALUPPO, M. C. Os princípios jurídicos no Estado Democrático de Direito: ensaio sobre o modo de sua aplicação. Revista de Informação Legislativa, Brasília, n. 143, p. 191-210, jul./set. 1999. 
GAMA, Guilherme Calmon Nogueira da; CIDAD, Felipe Germano Cacicedo. Função social no direito privado e constituição. In: GAMA, Guilherme Calmon Nogueira da (Coord.). Função social no Direito Civil. 2. ed. São Paulo: Atlas, 2008. p. 18-38.

GAMA, Guilherme Calmon Nogueira da; PEREIRA, Daniel Queiroz. Função social no direito privado e constituição. In: GAMA, Guilherme Calmon Nogueira da (Coord.). Função social no Direito Civil. 2. ed. São Paulo: Atlas, 2008. p. 68-91.

GAMA, Guilherme Calmon Nogueira da. Direito contratual contemporâneo: a função social do contrato. In: TEPEDINO, Gustavo; FACHIN, Luiz Edson (Coord.). O direito e o tempo: embates jurídicos e utopias contemporâneas. Rio de Janeiro: Renovar, 2008. p. 369-393.

GODOY, Claudio Luiz Bueno de. Função social do contrato. São Paulo: Saraiva, 2004.

GUASTINI, Riccardo. L'interpretazione dei documenti normativi. Milano: Giuffrè, 2004.

GÜNTHER, Klaus. Teoria da Argumentação no Direito e na moral: justificação e aplicação. São Paulo: Landy Editora, 2004.

HABERMAS, Jürgen. Between Facts and Norms: contributions to a discourse theory of law and democracy. Cambridge: MIT Press, 1998.

HIRONAKA, Giselda Maria Fernandes Novaes. A função social do contrato. Revista de Direito Civil, Imobiliário, Agrário e Empresarial, São Paulo, n. 45, p. 141-152, jul./set. 1988.

JÚNIOR, E. Da Responsabilidade Civil de terceiro por lesão do Direito de Crédito. Coimbra: Almedina, 2003.

KONDER, Carlos Nelson. Causa do contrato x função social do contrato: estudo comparativo sobre o controle da autonomia negocial. Revista trimestral de direito civil, Rio de Janeiro, v. 43, p. 33-75, jul./set. 2010.

KONDER, Carlos Nelson. Contratos conexos: grupos de contratos, redes contratuais e contratos coligados. Rio de Janeiro: Renovar, 2006.

LOBO, Paulo Luiz Netto. Princípios sociais dos contratos no Código de Defesa do Consumidor e no novo Código Civil. Revista de Direito do Consumidor, São Paulo, n. 42, p. 187-195, 2002.

MAIA, Antônio Cavalcanti. Notas sobre direito e argumentação. In: CAMARGO, Margarida Lacombe (Org.). 1988-1998: uma década de Constituição. Rio de Janeiro: Renovar, 1999. p. 395-431.

MARTINS-COSTA, Judith. A boa-fé no Direito Privado. São Paulo: Revista dos Tribunais, 1999. 
MELLO, Adriana Mandim Theodoro de. A função social do contrato e o princípio da boa-fé no Código Civil Brasileiro. Revista Forense, Rio de Janeiro, n. 364, p. 3-19, nov./dez. 2002.

MELLO, Celso Antônio Bandeira de. Novos aspectos da função social da propriedade no direito público. Revista de Direito Público - RDP, São Paulo, v. 84/39, p. 933-942, out./dez. 1987.

MELLO, Cláudio Ari. Interpretação jurídica e dever de fundamentação das decisões judiciais no novo código de processo civil. Revista de Processo, São Paulo, v. 41, n. 255, p. 63-90, maio 2016.

NALIN, Paulo. A função social do contrato no futuro Código Civil brasileiro. Revista de Direito Privado, São Paulo, n. 12, p. 50-60, out./dez. 2002.

NEGREIROS, Teresa. O princípio da boa-fé contratual. In: MORAES, Maria Celina Bodin de (Coord.). Princípios do Direito Civil contemporâneo. Rio de Janeiro: Renovar, 2006. p. 221-253.

NEGREIROS, Teresa. Teoria do contrato: novos paradigmas. Rio de Janeiro: Renovar, 2002.

OLIVEIRA, Leandro Corrêa de; SILVA FILHO, Edson Vieira da. A decisão jurídica entre o dever de fundamentação e a relativização dos discursos ajudicadores. Revista de Direito Constitucional e Internacional, São Paulo, v. 24, n. 95, p. 247-270, abr./jun. 2016.

ORLEANS, Helen Cristina Leite de Lima. Não basta ser proprietário, tem que participar: algumas notas sobre a função social da propriedade imobiliária no direito brasileiro. Revista de Direito Privado, São Paulo, v. 46, p. 99-146, abr./jun. 2011.

PERELMAN, Chaïm; OLBRECHTS-TYTECA, Lucie. Tratado da argumentação: a nova retórica. 2. ed. São Paulo: Martins Fontes, 2005.

PERLINGIERI, Pietro. O Direito Civil na legalidade constitucional. Rio de Janeiro: Renovar, 2008.

PERLINGIERI, Pietro. Perfis do Direito Civil. Rio de Janeiro: Renovar, 1999.

REALE, Miguel. Visão geral do projeto de Código Civil. Disponível em: <http://goo.gl/tNxAaW>. Acesso em: 9 jul. 2016.

RENTERÍA, Pablo. Considerações acerca do atual debate sobre o princípio da função social do contrato. In: MORAES, M. C. B. de. Princípios do Direito Civil contemporâneo. Rio de Janeiro: Renovar, 2006. p. 281-313.

ROQUE, André Vasconcelos. Dever de motivação das decisões judiciais e controle da jurisprudência no novo CPC. In: FREIRE, Alexandre et al. (Org.). Novas tendências do Processo Civil: estudos sobre o projeto de novo Código de Processo Civil. Salvador: Juspodium, 2013. p. 245-262. 
SARMENTO, Daniel. Ubiqüidade constitucional: os dois lados da moeda. In: SOUZA NETO, Cláudio Pereira de; SARMENTO, Daniel (Coord.). A Constitucionalização do Direito. Rio de Janeiro: Lumen Juris, 2007.

SCALABRIN, Felipe; SANTANNA, Gustavo. A legitimação pela fundamentação: anotação ao art. 489, § 1. ${ }^{\circ}$ e $\S 2 .^{\circ}$, do novo Código de Processo Civil. Revista de Processo, São Paulo, v. 41, n. 255, p. 17-40, maio 2016.

SCHLESINGER, Piero. Interpretazione della legge civile e prassi delle corti. Rivista di Diritto Civile, Padova, ano XLVII, parte prima, 2002.

SCHREIBER, Anderson. A proibição de comportamento contraditório: tutela da confiança e venire contra factum proprium. Rio de Janeiro: Renovar, 2005.

SILVA, Jorge Cesa Ferreira da. Princípios de direito das obrigações no novo Código Civil. In: SARLET, Ingo Wolfgang (Org.). O Novo Código Civil e a Constituição. Porto Alegre: Livraria do advogado, 2003.

SILVA, Luis Renato Ferreira da. A função social do contrato no novo Código Civil e sua conexão com a solidariedade social. In: Sarlet, Ingo Wolfgang (Org.). O Novo Código Civil e a Constituição. Porto Alegre: Livraria do advogado, 2003. p. 127-150.

SOUZA, Eduardo Nunes. Função negocial e função social do contrato: subsídios para um estudo comparativo. Revista de Direito Privado, São Paulo, v. 54, p. 65-87, abr. 2013.

STRECK, Lenio Luiz. O pan-principiologismo e o sorriso do lagarto. Revista Direito UNIFACS - Debate Virtual, Florianópolis, n. 144, jun. 2012.

SZANIAWSKI, Elimar. Aspectos da propriedade imobiliária contemporânea e sua função social. Revista de Direito Privado, São Paulo, v. 3, p. 126-156, jul./set. 2000.

SZTAJN, Rachel. Propriedade e contrato: função social. Revista de Direito Empresarial, São Paulo, v. 9, p. 453-459, maio/jun. 2015.

TARTUCE, Flávio. Função social dos contratos. São Paulo: Método, 2007.

TARUFFO, Michele. A motivação da sentença cível. São Paulo: Marcial Pons, 2015.

TEPEDINO, Gustavo; SCHREIBER, Anderson. O princípio da boa-fé objetiva no Código Civil e no Código de Defesa do Consumidor. In: TEPEDINO, Gustavo (Org.). Obrigações: estudos na perspectiva civil-constitucional. Rio de Janeiro: Renovar, 2005. p. 29-44.

TEPEDINO, Gustavo. Notas sobre a função social dos contratos. In: TEPEDINO, Gustavo; FACHIN, Luiz Edson (Coord.). O direito e o tempo: embates jurídicos e utopias contemporâneas. Rio de Janeiro: Renovar, 2008. p. 395-405. 
TEPEDINO, Gustavo. Temas de Direito Civil. 4. ed. Rio de Janeiro: Renovar, 2008. THEODORO JÚNIOR, Humberto et al. Novo CPC: fundamentos e sistematização. Rio de Janeiro: Forense, 2015.

THEODORO JÚNIOR, Humberto. O contrato e sua função social. Rio de Janeiro: Forense, 2004.

TIMM, Luciano Benetti. Função social do direito contratual no Código Civil brasileiro: justiça distributiva vs. eficiência econômica. Revista dos Tribunais, São Paulo, v. 876, p. 11-28, out. 2008.

1 ROQUE, André Vasconcelos. Dever de motivação das decisões judiciais e controle da jurisprudência no novo CPC. In: FREIRE, Alexandre et al. (Orgs). Novas tendências do processo civil: estudos sobre o projeto de novo Código de Processo Civil. Salvador: Juspodium, 2013. p. 249-250.

2 FUX, Luiz. Prefácio. In: FREIRE, Alexandre et al. (Org.). Novas tendências do processo civil: estudos sobre o projeto de novo Código de Processo Civil. Salvador: Juspodium, 2013. p. 9.

3 THEODORO JR., Humberto et al. Novo CPC: fundamentos e sistematização. Rio de Janeiro: Forense, 2015. p. 842-844.

4 TARUFFO, Michele. A motivação da sentença cível. São Paulo: Marcial Pons, 2015, passim.

5 SARMENTO, Daniel. Ubiqüidade constitucional: os dois lados da moeda. In: SOUZA NETO, Cláudio Pereira de; SARMENTO, Daniel (Coord.). A constitucionalização do direito. Rio de Janeiro, Lumen Juris, 2007. p. 113-148.

6 STRECK, Lenio Luiz. O pan-principiologismo e o sorriso do lagarto. Revista Direito UNIFACS Debate Virtual, Florianópolis, n. 144, jun. 2012.

7 OLIVEIRA, Leandro Corrêa de; SILVA FILHO, Edson Vieira da. A decisão jurídica entre o dever de fundamentação e a relativização dos discursos ajudicadores. Revista de Direito Constitucional e Internacional, São Paulo, v. 24, n. 95, p. 247-270, abr.jun. 2016.

8 SCALABRIN, Felipe; SANTANNA, Gustavo. A legitimação pela fundamentação: anotação ao art. $489, \S 1 .^{\circ}$ e $\S 2 .^{\circ}$, do Novo Código de Processo Civil. Revista de Processo, São Paulo, v. 41, n. 255, p. 17-40, maio 2016.

9 THEODORO JR., Humberto et al. Novo CPC: fundamentos e sistematização. Rio de Janeiro: Forense, 2015. p. 967-970.

10 MELLO, Cláudio Ari. Interpretação jurídica e dever de fundamentação das decisões judiciais no novo código de processo civil. Revista de Processo, São Paulo, v. 41, n. 255, p. 63-90, maio 2016.

11 OLIVEIRA, Leandro Corrêa de; SILVA FILHO, Edson Vieira da. A decisão jurídica entre o dever de fundamentação e a relativização dos discursos ajudicadores. Revista de Direito Constitucional e Internacional, São Paulo, v. 24, n. 95, p. 247-270, abr.jun. 2016.

12 CAMARGO, Margarida Lacombe. Hermenêutica e argumentação: uma contribuição ao estudo do Direito. 3. ed. Rio de Janeiro: Renovar, 2003. p. 137.

13 PERELMAN, Chaïm; OLBRECHTS-TYTECA, Lucie. Tratado da argumentação: a nova retórica. 2. ed. São Paulo: Martins Fontes, 2005. p. 1.

14 ALEXY, Robert. Teoria da argumentação jurídica. 2. ed. São Paulo: Landy, 2005. p. 212.

15 Dentre a vasta produção científica que recebeu nos últimos anos, destaca-se Humberto ÁVILA, para quem o postulado da razoabilidade se manifesta sob três acepções: "Primeiro, a razoabilidade é utilizada como diretriz que exige a relação das normas gerais com as individualidades do caso concreto, quer mostrando sob qual perspectiva a norma deve ser aplicada, quer indicando em quais hipóteses o caso individual, em virtude de suas especificidades, deixa de se enquadrar na norma geral. Segundo, a razoabilidade é empregada como diretriz que exige uma vinculação das normas jurídicas com o mundo ao qual elas fazem referência, seja reclamando a existência de um suporte empírico e adequado a qualquer ato jurídico, seja demandando uma relação congruente entre a medida adotada e o fim que ela pretende atingir. Terceiro, a razoabilidade é utilizada como diretriz que exige a relação de equivalência entre duas grandezas" (Teoria dos princípios. 5. ed. São Paulo: Malheiros, 2006. p. 139). 
16 HABERMAS, Jürgen. Between facts and norms: contributions to a discourse theory of law and democracy. Cambridge: MIT Press, 1998, passim.

17 PERLINGIERI, Pietro. O direito civil na legalidade constitucional. Rio de Janeiro: Renovar, 2008. p. 96.

18 SCHLESINGER, Piero. Interpretazione della legge civile e prassi delle corti. Rivista di diritto civile, Padova, ano XLVII, parte prima, p. 540-541, 2002.

19 GUASTINI, Riccardo. L'interpretazione dei documenti normativi. Milano: Giuffrè, 2004. p. 113.

20 MAIA, Antônio Cavalcanti. Notas sobre direito e argumentação. In: CAMARGO, Margarida Lacombe (Org.). 1988-1998: uma década de constituição. Rio de Janeiro: Renovar, 1999. p. 413.

21 ATIENZA, Manuel. As razões do direito: teorias da argumentação jurídica. 3. ed. São Paulo: Landy, 2006. p. 23.

22 A expressão é de ENGISCH, Karl. La idea de concreción en el derecho y en la ciencia jurídica actuales. Pamplona: Universidad de Navarra, 1968, passim.

23 ENGISCH, Karl. Introdução ao pensamento jurídico. 10. ed. Lisboa: Fundação Calouste Gulbenkian, 2008. p. 205 e ss.

24 Ibid, p. 208.

25 Ibid, p. 228.

26 MARTINS-COSTA, Judith. A boa fé no direito privado. São Paulo: Revista dos Tribunais, 1999. p. 303.

27 REALE, Miguel. Visão geral do projeto de código civil. Disponível em: <http://goo.gl/tNxAaW>. Acesso em: 9 jul. 2016.

28 MARTINS-COSTA, Judith. A boa-fé no direito privado. São Paulo: Revista dos Tribunais, 1999. p. 323.

29 Sobre a mudança da concepção de princípio, v. BONAVIDES, Paulo. Curso de direito constitucional. São Paulo, Malheiros, 2000. p. 232-238. Para um enfoque desta transformação histórica no âmbito do direito civil, v. TEPEDINO, Gustavo. Premissas metodológicas para a constitucionalização do direito civil. Temas de direito civil. 3 ed, Rio de Janeiro, Renovar, 2004. p. 1-22.

30 ALEXY, Robert. Teoría de los derechos fundamentales. Madrid: Centro de Estudios Constitucionales, 1993. p. 86-87.

31 Normalmente estas duas correntes são aproximadas pela doutrina (especialmente no sentido de incluir Dworkin na primeira, junto com Alexy, sem relevar suas distinções), como, por exemplo, pelo pioneiro BONAVIDES, Paulo. Curso de Direito Constitucional. São Paulo, Malheiros, 2000. p. 248.

32 Para uma comparação crítica das duas correntes, v. GALUPPO, M. C. Os princípios jurídicos no Estado Democrático de Direito: ensaio sobre o modo de sua aplicação. Revista de Informação Legislativa, $n$. 143, p. 191-210, jul./set. 1999, especialmente p. 196.

33 Neste sentido os princípios se distinguem das diretrizes políticas (passíveis de ponderação), como afirma DWORKIN, Ronald. Levando os direitos a sério. São Paulo, Martins Fontes, 2002. p. 36 e ss.

34 HABERMAS, Jürgen. Between facts and norms: contributions to a discourse theory of law and democracy. Cambridge: MIT Press, 1998. p. 255 e ss.

35 GÜNTHER, Klaus. Teoria da argumentação no direito e na moral: justificação e aplicação. São Paulo: Landy Editora, 2004. especialmente p. 367 e ss.

36 DWORKIN, Ronald, op. cit., pp. 39 e ss.

37 GALUPPO, M. C., op. cit., p. 195.

38 HABERMAS, Jürgen, op. cit., pp. 217 e ss.

39 Sobre o tema, entre tantos, v. CORDEIRO, António Menezes. Da boa fé no direito civil. Coimbra: Almedina, 1997; e, entre nós, MARTINS-COSTA, Judith. A boa-fé no direito privado. São Paulo: Revista dos Tribunais, 1999; NEGREIROS, Teresa. O princípio da boa-fé contratual. In: MORAES, Maria Celina Bodin de (Coord.). Princípios do direito civil contemporâneo. Rio de Janeiro: Renovar, 2006. p. 221-253; SILVA, Jorge Cesa Ferreira da. Princípios de direito das obrigações no Novo Código Civil. In: SARLET, Ingo Wolfgang (Org.). O Novo Código Civil e a Constituição. Porto Alegre: Livraria do advogado, 2003. p. 99-126; TEPEDINO, Gustavo; SCHREIBER, Anderson. O princípio da boa-fé objetiva no Código Civil e no Código de Defesa do Consumidor. In: TEPEDINO, Gustavo (Org.). Obrigações: estudos na perspectiva civil-constitucional. Rio de Janeiro: Renovar, 2005. p. 29-44.

40 TJRJ, $10^{a}$ C.C., Ap. Cível n. 0342914-23.2008.8.19.0001, Rel. Des. Pedro Saraiva Andrade Lemos, julg. 27/08/2015; TJRJ, $15^{\text {a }}$ C.C., Ap. Cível n. 0174951-48.2012.8.19.0001; Des. Maria Regina Nova Alves. Julgamento em 22.06 .15

41 TJRJ, $13^{\text {a }}$ C.C., Ap. Cível n. 0452248-84.2011.8.19.0001, Des. Fernando Fernandy Fernandes, julg. $18 / 12 / 2015$. 
42 TJRJ, $20^{\text {a }}$ C.C., Ap. Cível n. 0097428-33.2007.8.19.0001, Rel. Des. Conceição Mousnier, julg. $22 / 05 / 2015$.

43 TJRJ, $21^{\text {a }}$ C.C., Ap. Cível n. 0122159-20.2012.8.19.0001, Rel. Des. Andre Ribeiro, julg. 18/8/2015.

44 TJRJ, 6 a C.C., Ap. Cível n. 0102284-35.2010.8.19.0001. Rel. Des. Nagib Slaibi. publ. DJ 25/11/15

45 TJRJ, 9a C.C., Ap. Cível n. 0394383-74.2009.8.19.0001, Rel. Des. Adolpho Andrade Mello, julg. 15/9/2015 e TJRJ, 14 a C.C., Ap. Cível n. 0015175-04.2011.8.19.0209, Rel. Des. Jose Carlos Paes, julg. 28/08/2015 e TJRJ, $18^{\text {a C}}$ C.C., Ap. Cível n. 0002018-23.2006.8.19.0052. Apelação. Des. Carlos Eduardo Passos, julg. 12/11/15.

46 TJRJ, $19^{a}$ C.C., Ap. Cível n. 0004674-59.2009.8.19.0209, Rel. Des. Valeria Dacheux, julg. 07/1/2015.

47 TJRJ, 19a C.C., Ag. Instr. n. 0046549-44.2015.8.19.0000, Rel. Des. Elton Leme, julg. 13/10/2015.

48 SCHREIBER, Anderson. A proibição de comportamento contraditório: tutela da confiança e venire contra factum proprium. Rio de Janeiro: Renovar, 2005. p. 114-120.

49 TJRJ, $1^{\text {a }}$ C.C., Ap. Cível n. 0001334-21.2012.8.19.0042, Rel. Des. Maldonado de Carvalho, julg. $02 / 10 / 2015$

50 TJRJ, $3^{\text {a }}$ C.C., Ap. Cível n. 0456662-28.2011.8.19.0001, Rel. Des. Mario Assis Gonçalves, julg. $01 / 07 / 2015$

51 TJRJ, 4a C.C., Ap. Cível n. 0005113-76.2014.8.19.0021, Rel. Des. Antonio Iloizio B. Bastos, julg. $14 / 12 / 2015$.

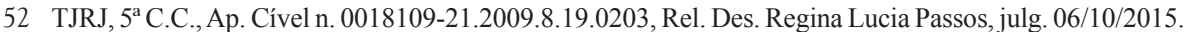

53 TJRJ, $7^{\text {a }}$ C.C., Ap. Cível n. 0000339-37.1994.8.19.0204, Rel. Des. Ricardo Couto, julg. 25.3.2015.

54 MARTINS-COSTA, Judith. A boa fé no direito privado. São Paulo: Revista dos Tribunais, 1999. p. 427 e ss.

55 EHRHARDT JR., Marcos. Responsabilidade civil pelo inadimplemento da boa-fé. Belo Horizonte: Forum, 2014. p. 98.

56 Por exemplo, a invocação do tu quoque no caso de um segurado que se limita a cobrar serviço do plano de saúde que paga em dia (TJRJ, $26^{a}$ C.C., Ap. Cível n. 0132616-43.2014.8.19.0001, Rel. Des. Natacha Tostes Oliveira, julg. 15/04/2015) e do venire para a anulação de ato administrativo que exonerou

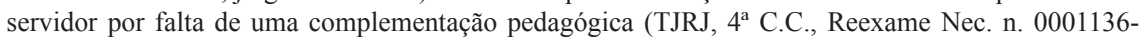
80.2012.8.19.0001, Rel. Des. Sidney Hartung, julg. 28/11/2014). Para uma crítica a essa superutilização da boa-fé objetiva, v. SCHREIBER, Anderson. A proibição de comportamento contraditório: tutela da confiança e venire contra factum proprium. Rio de Janeiro: Renovar, 2005. p. 114-120.

57 HIRONAKA, Giselda Maria Fernandes Novaes. A função social do contrato. Revista de Direito Civil, Imobiliário, Agrário e Empresarial, São Paulo, n. 45, p. 141-152, jul./set. 1988.

58 AZEVEDO, Antônio Junqueira de. Entrevista concedida à Revista trimestral de direito civil, Rio de Janeiro, n. 34, p. 305, abr./jun. 2008.

59 TJDF, $1^{\text {a }}$ Turma Cível, Ap. Cível 20020111044353, Rel. Flavio Rostirola, julg. 11/6/2008, publ. DJU $14 / 07 / 2008$.

60 TJRS, $8^{a}$ C.C., Ap. Cível n. 70017926536, Rel. Pedro Celso Dal Pra, julg. 15/2/2007. Indicam que este tipo de referência à função social do contrato antecede a expressa previsão do Código Civil de 2002 GAMA, Guilherme Calmon Nogueira da; PEREIRA, Daniel Queiroz. Função social no direito privado e constituição. In: GAMA, Guilherme Calmon Nogueira da (Coord.). Função social no direito civil. 2. ed. São Paulo: Atlas, 2008. p. 79-80.

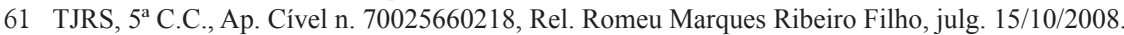

62 TJRS, $9^{a}$ C.C., Ap. Cível n. 70025542754, Rel. Léo Romi Pilau Júnior, julg. 08/10/2008.

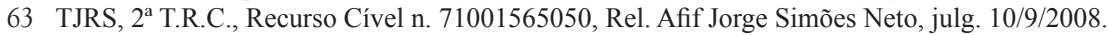

64 TJRS, $2^{\text {a }}$ T.R.C., Recurso Cível n. 71000693143, Rel. Mylene Maria Michel, julg. 17/5/2006.

65 TJRJ, $2^{\text {a }}$ C.C., Ag. Instr. 2008.002.33382, Rel. Des. Paulo Sergio Prestes, julg. 13/10/2008; TJRJ, $15^{\text {a }}$ C.C., Ag. Instr. 2008.002.15589, Rel. Des. Jose Carlos Paes, julg. 28/5/2008.

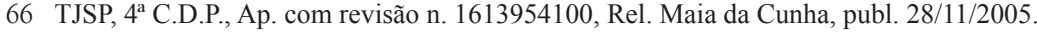

67 TJDF, $3^{\text {a }}$ T.C., APC 20060110408947, Rel. Humberto Adjuto Ulhôa, julg. 12/03/2008 publ. DJU $03 / 04 / 2008$

68 TJRJ, 16 a C.C., Ap. 2008.001.49662, Rel. Des. Marco Aurelio Bezerra De Melo, julg. 14/10/2008; TJMG, proc. n. 1.0701.06.170086-3/001(1), Rel. Valdez Leite Machado, julg. 24/7/2008, publ. 20/08/2008; TJSP, $14^{a}$ C.D.P., Ap. n. 1311473700, Rel. Ligia Araújo Bisogni, julg. 27/9/2008, publ. 24/10/2008; TJRS, $14^{\text {a }}$ C.C., Ap. Cível n. 70025542754, Rel. Dorval Bráulio Marques, julg. 14/8/2008. 
69 RENTERÍA, Pablo. Considerações acerca do atual debate sobre o princípio da função social do contrato. In: MORAES, M. C. B. de. Princípios do direito civil contemporâneo. Rio de Janeiro: Renovar, 2006. p. 287-288. Por isso, diversos autores preferem reservar estes efeitos aos princípios da boa-fé e do equilíbrio econômico, atribuindo à função social somente a chamada eficácia externa: THEODORO JÚNIOR, Humberto. O contrato e sua função social. Rio de Janeiro: Forense, 2004. p. 31; SILVA, Luis Renato Ferreira da. A função social do contrato no novo Código Civil e sua conexão com a solidariedade social. In: SARLET, Ingo Wolfgang (Org.). O novo Código Civil e a Constituição. Porto Alegre: Livraria do advogado, 2003. p. 127-150; SILVA, Jorge Cesa Ferreira da. Princípios de direito das obrigações no novo Código Civil. In: SARLet, Ingo Wolfgang (Org.). O novo Código Civil e a Constituição. Porto Alegre: Livraria do advogado, 2003. p. 99-126.

70 TEPEDINO, Gustavo. Notas sobre a função social dos contratos. In: TEPEDINO, Gustavo; FACHIN, Luiz Edson (Coord.). O direito e o tempo: embates jurídicos e utopias contemporâneas. Rio de Janeiro: Renovar, 2008. p. 396-397.

71 PERLINGIERI, Pietro. Perfis do direito civil. Rio de Janeiro: Renovar, 1997. p. 279

72 TJSP, $11^{\text {a }}$ C.D.Publ., proc. n. 7248535000, Rel. Francisco Vicente Rossi, publ. 23/10/2008.

$73 \mathrm{O}$ alerta é de que a expressão função social no direito privado "pôde ser utilizada por diversas teorias econômicas para justificar inumeráveis ações estatais limitadoras das liberdades individuais. Do socialismo ao fascismo, a exigência de uma conduta privada na conformidade com o coletivo espalhava-se com relativa aceitação nas sociedades européias da segunda década do século XX" (GAMA, Guilherme Calmon Nogueira da; CIDAD, Felipe Germano Cacicedo. Função social no direito privado e constituição. In: GAMA, Guilherme Calmon Nogueira da (Coord.). Função social no direito civil. 2. ed. São Paulo: Atlas, 2008. p. 19).

74 LOBO, Paulo Luiz Netto. Princípios sociais dos contratos no Código de Defesa do Consumidor e no novo Código Civil. Revista de direito do consumidor, São Paulo, n. 42, p. 191, 2002.

75 Incluem-se ainda nesta lista "o respeito à cultura, ao desenvolvimento do ensino científico e do desporto, além do meio ambiente" (GAMA, Guilherme Calmon Nogueira da; CIDAD, Felipe Germano Cacicedo. Função social no direito privado e constituição. In: GAMA, Guilherme Calmon Nogueira da (Coord.). Função social no direito civil. 2. ed. São Paulo: Atlas, 2008. p. 35).

76 Assim, GAMA, Guilherme Calmon Nogueira da; CIDAD, Felipe Germano Cacicedo. Função social no direito privado e constituição. In: GAMA, Guilherme Calmon Nogueira da (Coord.). Função social no direito civil. 2. ed. São Paulo: Atlas, 2008. p. 32, para quem "o intérprete, ao realizar sua atividade de concretizar cláusulas gerais e conceitos jurídicos indeterminados, deve considerar os direitos fundamentais previstos no texto constitucional sem que, por isso, o litígio deixe de ser de natureza intersubjetiva (privada), mesmo que informado pelos valores e princípios constitucionais".

77 TJDF, 4a T. C., proc. 20070111078052, rel. Maria Beatriz Parrilha, julg. 02/7/2008, publ. 08/9/2008.

78 STJ, $3^{\text {a }}$ T., REsp 811670, Rel. Min. Nancy Andrighi, julg. 16/11/2006, publ. DJ 04/12/2006; TJRS, $9^{a}$ C.C., Ap. Cível n. 70022284731, rel. Odone Sanguiné, julg. 16/4/2008; TJSP, $9^{a}$ C.D.P., Ag. Instr. 5245314900, Rel. Grava Brazil, julg. 25/9/2007, publ. 17/10/2007. No caso específico de atribuição de legitimidade para a cessionária do financiamento, STJ, $1^{\text {a }}$ T., REsp 627424, Rel. Min. Luiz Fux, julg. 06/3/2007, publ. DJ 28/5/2007.

79 TJRS, $5^{\text {a }}$ C.C., Ap. Cível n. 70026788521, Rel. Jorge Luiz Lopes do Canto, julg. 15/10/2008; TJRS, $5^{\text {a }}$ C.C., Ag. Instr. n. 70026516435, Rel. Jorge Luiz Lopes do Canto, julg. 15/10/2008; TJRJ, 15a C.C., Ap. Cível. 2008.001.42010, Rel. Helda Lima Meireles, julg. 01/07/2008; TJSP, $4^{\text {a }}$ T.C., Recurso Inominado 11449, Rel. Maria do Carmo Honorio, julg. 08/7/2008, publ. 23/10/2008; TJDF, $1^{\text {a }}$ T. C., Ag. Instr. 20080020101970, Rel. Natanael Caetano, julg. 24/9/2008, publ. 29/9/2008.

80 TJRJ, $2^{\text {a }}$ C.C., Ap. Cível. 2008.001.47220, Rel. Carlos Eduardo Passos, julg. 10/9/2008.

81 STJ, $3^{\text {a }}$ S., EDcl nos EREsp 791077, Rel. Min. Arnaldo Esteves Lima, julg. 23/4/2008, publ. DJ 21/8/2008.

82 Sobre a importância de considerar as distinções entre os contratos ao aplicar a função social, v. GAMA, Guilherme Calmon Nogueira da. Direito contratual contemporâneo: a função social do contrato. In: TEPEDINO, Gustavo; FACHIN, Luiz Edson (Coord.). O direito e o tempo: embates jurídicos e utopias contemporâneas. Rio de Janeiro: Renovar, 2008. p. 369-393.

83 TEPEDINO, Gustavo. Notas sobre a função social dos contratos. In: TEPEDINO, Gustavo; FACHIN, Luiz Edson (Coord.). O direito e o tempo: embates jurídicos e utopias contemporâneas. Rio de Janeiro: Renovar, 2008. p. 402.

84 CAVALIERI FILHO, Sérgio. O novo Código Civil e o Código do Consumidor: convergências ou antinomias. Revista da EMERJ, Rio de Janeiro, v. 5, n. 20, p. 110, 2002. 
85 HIRONAKA, Giselda Maria Fernandes Novaes. A função social do contrato. Revista de Direito Civil, Imobiliário, Agrário e Empresarial, São Paulo, n. 45, p. 138, jul./set. 1988.

86 STJ, $3^{\text {a }}$ T., REsp 476649, Rel. Min. Nancy Andrighi, julg. 20/11/2003, publ. DJ 25/2/2004

87 TAPR, AC n. 263.725-6, Rel. Des. Wilde de Lima Pugliese, publ. 10/9/2004.

88 TJSP, proc. 4500574100, Rel. Elcio Trujillo, publ. 25/9/2006.

\title{
CONTRACTUAL PRINCIPLES AND THE REQUIREMENT OF REASONING FOR DECISIONS: GOOD FAITH AND THE SOCIAL FUNCTION OF CONTRACTS UNDER THE CIVIL PROCEDURE CODE OF 2015
}

\begin{abstract}
This paper analyzes the impact of the introduction, by the Civil Procedure Code of 2015, of parameters that will allow for the assessment of the appropriate reasoning for judicial decisions on the application of contractual principles, more specifically, the principles of good faith and the social function of contracts. The article is grounded on the contributions of the theory of contemporary argumentation, incorporated by the procedural doctrine, particularly with regards to normative structures such as principles, general provisions and indeterminate concepts. The paper then analyzes a representative sample of court decisions which represent the criticism presented by the doctrine sustaining the occurrence of mentions of merely a rhetorical character of contractual principles, as a way of justifying the interpreter's own personal understanding. Finally, it indicates instruments for the interpreter to discharge more properly of the argumentative burden of justifying decisions through suggested doctrinally constructed or constitutionally positivized discursive topoi, as the so-called functional specializations or partial figures of good faith and legal interests, to which the constituent powers refer as able to give content to the social function of contracts, such as education, health, housing and environment.
\end{abstract}

Keywords: Reasoning. Principles. Good faith. Social function of contracts.

Submetido: 1 set. 2016

Aprovado: 5 out. 2016 